\title{
Determining the Compressive, Flexural and Splitting Tensile Strength of Silica Fume Reinforced Lightweight Foamed Concrete
}

\author{
M.A.O. Mydin ${ }^{1, a}$, N. Md. Sani ${ }^{2}$, M.A. Mohd Yusoff ${ }^{3}$, S. Ganesan ${ }^{4}$ \\ ${ }^{1,2,3,4}$ School of Housing, Building and Planning, Universiti Sains Malaysia, 11800, Penang, Malaysia
}

\begin{abstract}
This study investigated the performance of the properties of foamed concrete in replacing volumes of cement of $10 \%, 15 \%$ and $20 \%$ by weight. A control unit of foamed concrete mixture made with ordinary Portland cement (OPC) and 10\%,15\% and $20 \%$ silica fume was prepared. Three mechanical property parameters were studied such as compressive strength, flexural strength and splitting tensile of foamed concrete with different percentages of silica fume. Silica fume is commonly used to increase the mechanical properties of concrete materials and it is also chosen due to certain economic reasons. The foamed concrete used in this study was cured at a relative humidity of $70 \%$ and a temperature of $\pm 28^{\circ} \mathrm{C}$. The improvement of mechanical properties was due to a significant densification in the microstructure of the cement paste matrix in the presence of silica fume hybrid supplementary binder as observed from micrographs obtained in the study. The overall results showed that there is a potential to utilize silica fume in foamed concrete, as there was a noticeable enhancement of thermal and mechanical properties with the addition of silica fume.
\end{abstract}

\section{Introduction}

For the past few years, the construction industry has shown noteworthy attention in the utilization of lightweight foamed concrete as a building material due to its many favourable characteristics such as lighter weight, ease of fabrication, durability and cost effectiveness [1,2]. Foamed concrete is a material consisting of Portland cement paste with a homogeneous pore structure created by introducing air in the form of small bubbles [3]. With a controlled dosage of foam and proper methods of production, a wide range of densities $\left(400-1600 \mathrm{~kg} / \mathrm{m}^{3}\right)$ of foamed concrete can be produced, hence, providing flexibility for application such as for structural elements, partitions, insulating materials and filling grades [4,5]. Foamed concrete has so far been applied primarily as a filler material in civil engineering works [6]. However, its good thermal and acoustic performance indicates its strong potential as a material in building construction [7].

Foamed concrete is a cement-bonded material made by blending an extremely fluid cement paste, into which is injected stable, pre-formed foam, manufactured on site [8]. Fresh foamed concrete has the appearance of a light-grey mousse or milk-shake and it has a slurry to foam volume which dictates the cast density of the foam concrete. The physical characteristics of foam concrete are

\footnotetext{
${ }^{\mathrm{a}}$ Corresponding author : azree@usm.my
} 
determined by the use of one of a number of mix designs. Depending upon the application for which the concrete is required, these mix designs may include the use of Portland Cement (CEM1), either on its own, or in combination with a percentage of silica fume. Foamed concrete blocks are lightweight and can be easily produced according to different densities when needed, therefore, saving in transportation costs. Furthermore, silica fume is an ultrafine powder collected as a by-product of the silicon and ferrosilicon alloy production and consists of spherical particles with an average particle diameter of $150 \mathrm{~nm}$ and compatible with concrete structures [9].

Silica fume for use in concrete can be found in wet or dry form, and it is usually added during the production of concrete. Silica fume has extremely small particles and is commonly used to increase the compressive strength of concrete materials. Silica fume concrete has been produced in both central mix and vegetation. Furthermore, silica fume is also known as micro silica, condensed silica fume, volatilized silica or silica dust [10].

Silica fume's potential for durability in lightweight foamed concrete is used to determine air water absorption. It is added in foam concrete in order to improve thermal and mechanical properties [11]. In this paper, for the purpose of describing and evaluating the microstructure of mineral-bound foams, light microscopy combined with digital image analysis as well as scanning electron microscopy were considered suitable tools. This study was conducted in response to the need for improved economic and ecologically friendly concrete while maintaining the existing goal of creating sustainable building materials.

\section{Materials}

\subsection{Cement}

Portland Cement CEM I with a specific surface area of $1043.2 \mathrm{~m}^{2} / \mathrm{kg}$, specific gravity of 3.02 and median particle size of $3.9 \mu \mathrm{m}$ was used for specimen preparation. Provisions were supplied by the School of Housing, Building and Planning, Universiti Sains Malaysia's concrete laboratory.

\subsection{Sand}

Uncrushed, fine sand was utilized in all foamed concrete mixes. The sand used possessed a specific gravity of 2.83 and had a maximum aggregate size of $5 \mathrm{~mm}$. The fine sand was graded in accordance to BS 812: Part 102 and the fitness modulus were determined to be 3.26 [12].

\subsection{Foam}

The type of foam used was a protein-based admixture application of foam concrete. The foam was made using a foam generator. It was stiff, like shaving foam, with a density of approximately 45 $\mathrm{g} /$ litre. The bubbles were stable and able to resist the physical and chemical forces imposed during mixing, placing and hardening of the foamed concrete [13].

\subsection{Silica Fume}

The mix proportion of lightweight foamed concrete used 3 different percentages of silica fume of $10 \%, 15 \%$ and $20 \%$. Silica fume for use in concrete can be found in wet and dry form. Dry form was selected as a compound in this study. Fig. 1 shows the particle size distribution of sand and silica fume.

\subsection{Water}

The ratio of water to cement for this study was 0.45 . The water-cement ratio describes the ratio of the weight of water to the weight of cement used in a concrete mix and has an important influence on the quality of the concrete produced. A lower water-cement ratio leads to higher strength and durability [14]. 


\section{Experimental Setup}

In order to determine the mechanical properties of foamed concrete with the addition of silica fume, three parameters were investigated: compressive strength, flexural strength and splitting tensile strength. The specimens for this test were three $100 \mathrm{~mm}$ cubes subjected to compression, three $100 \times 100 \times 500 \mathrm{~mm}$ prisms subjected to flexural strength and three $100 \times 300 \mathrm{~mm}$ cylinders subjected to splitting tests. All of the samples were tested on days 7 and 28 after one day of curing in an oven. Fig. 3 shows the equipment (GOTECH GT-7001-BS300) used for the compression test.
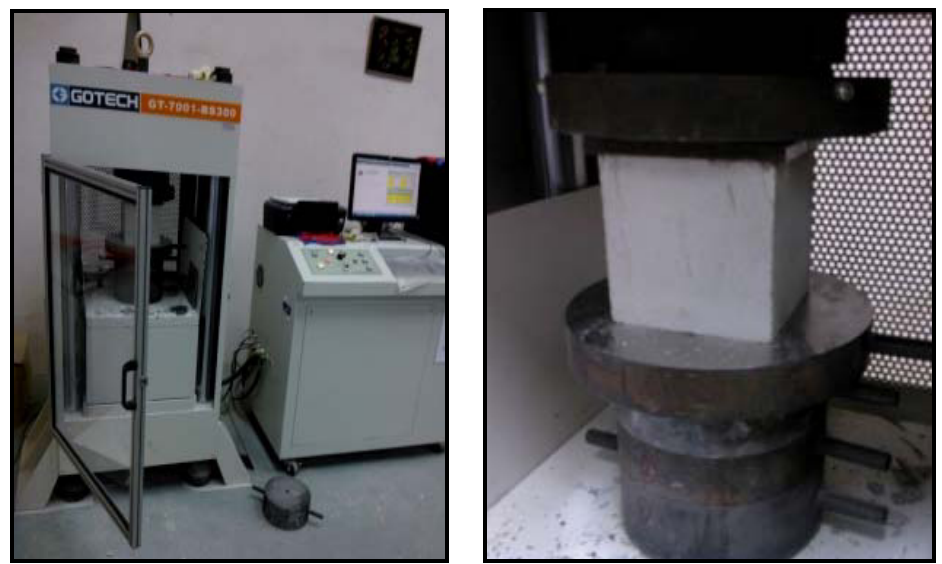

Fig. 3: GOTECH GT-7001-BS300, a closed-loop servo-hydraulic dynamic of 300 tan-capacity machine

\section{Results and Discussion}

\subsection{Compressive Strength}

The compressive strength of control foamed concrete mixes was compared to different proportions of silica fume at $10 \%, 15 \%$ and $20 \%$. At 7 days, the compressive strengths of $10 \%$ silica fume and $15 \%$ silica fume were found to be higher than control foamed concrete, but for $20 \%$ silica fume, the compressive strength was recorded to be lower compared to that of the control mix. It can be seen from Fig. 9 that $15 \%$ silica fume presented the highest compressive strength.

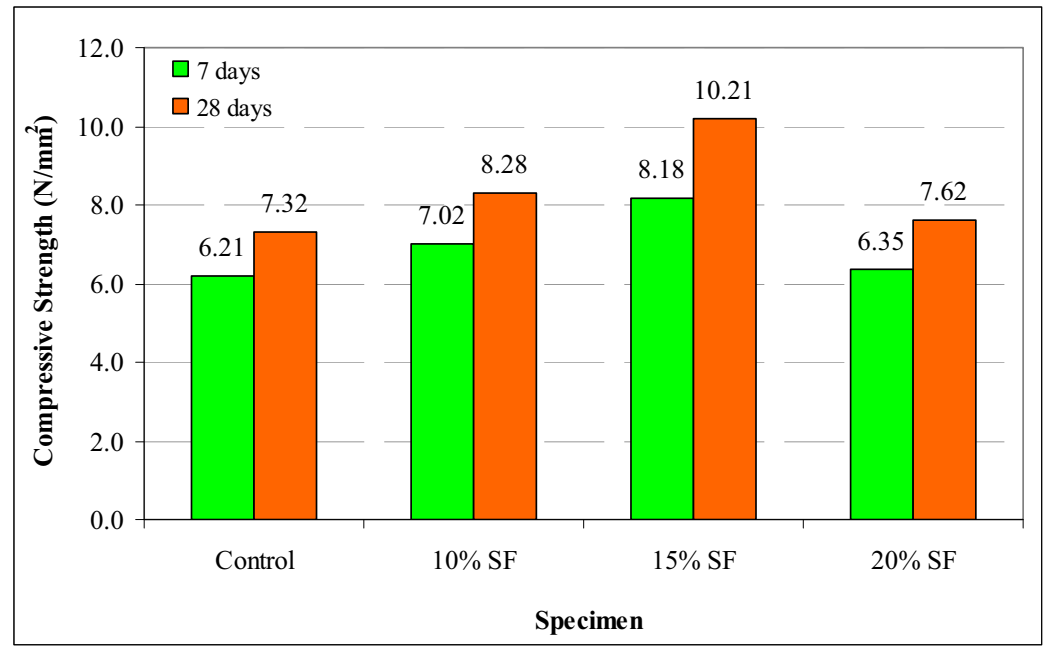

Fig. 9: Comparison of compressive strength of different percentages of silica fume at 7 and 28 days 
Meanwhile, at 28 days, the compressive strength of $15 \%$ silica fume was higher than the control mix, $10 \%$ silica fume and $20 \%$ silica fume. For $20 \%$ silica fume foamed concrete, the resulting compressive strength was lower than the control mix. The best result for compressive strength was from the $15 \%$ silica fume. It produced the highest strength, with compressive strength measuring beyond $10.21 \mathrm{~N} / \mathrm{mm}^{2}$ at the 28 day mark.

\subsection{Flexural Strength}

Flexural strength was used to examine the foamed concrete specimens bending behaviour at the maximum load of failure. The flexural strength of samples containing silica fume were compared to different proportions of this mix. Trends were observed throughout the entire duration of curing up to 28 days. For the flexural strength of mortars at 7 days, the foamed concrete sample with $15 \%$ silica fume was higher than other mixes. In addition, the flexural strength of the mortar sample mix with $20 \%$ silica fume was found to decrease more than the mortar sample mixes with $10 \%$ silica fume and $15 \%$ silica fume, but it measured higher than the control mortar. At 28 days, it was found that the mortar sample mix with $15 \%$ silica fume had a good strength. Meanwhile, the $20 \%$ silica fume mortar decreased but was still higher than the control mortar. The flexural strength of the mortar with $20 \%$ silica fume was lower than the mortars with $10 \%$ silica fume and $15 \%$ silica fume. Focusing on long term preservation of flexural strength at the age of 28 days, a significant increase in flexural strength of $1.41 \mathrm{~N} / \mathrm{mm}^{2}$ was exhibited by the $15 \%$ silica fume.

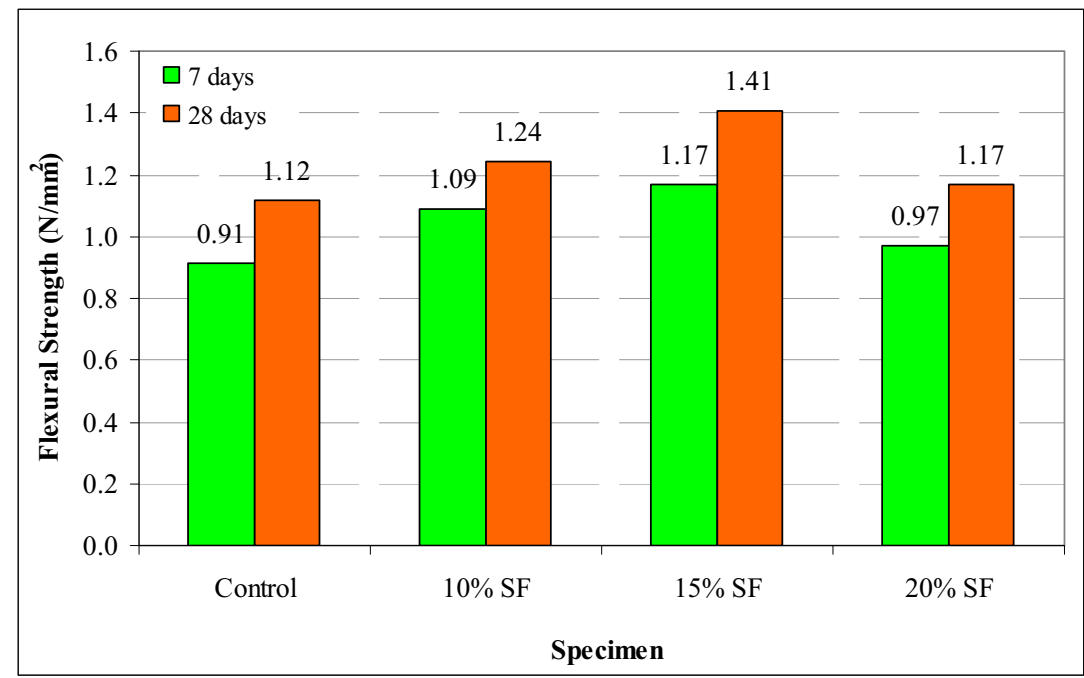

Fig. 10: Comparison of flexural strength of different percentages of silica fume at 7 and 28 days

\subsection{Splitting Tensile Strength}

The trends observed in the splitting tensile strength of the $10 \%, 15 \%$ and $20 \%$ silica fume were used to compare the strength of the sample. Observations were made throughout the duration of the 28 days. At 7 days, the splitting tensile strength of the specimens with $15 \%$ silica fume was found to be significantly higher than other mortar mixes. Additionally, the $10 \%$ silica fume and the $20 \%$ silica fume measured higher in comparison with the control mortar. However, the $20 \%$ silica fume was much lower compared with the $10 \%$ silica fume and the $15 \%$ silica fume. At 28 days, measuring $1,74 \mathrm{~N} / \mathrm{mm}^{2}$, the splitting tensile strength of the $15 \%$ silica fume mortar was significantly higher than the other mortars. The tensile strength of the $20 \%$ silica fume mortar was higher than the control mortar but lower than the mortars containing $10 \%$ silica fume and $15 \%$ silica fume. In the long run, 
coring of 28 days resulted in a significant enhancement in tensile strength as exhibited by the mortar mix with $15 \%$ silica fume which produced an observed strength of $1.74 \mathrm{~N} / \mathrm{mm}^{2}$.

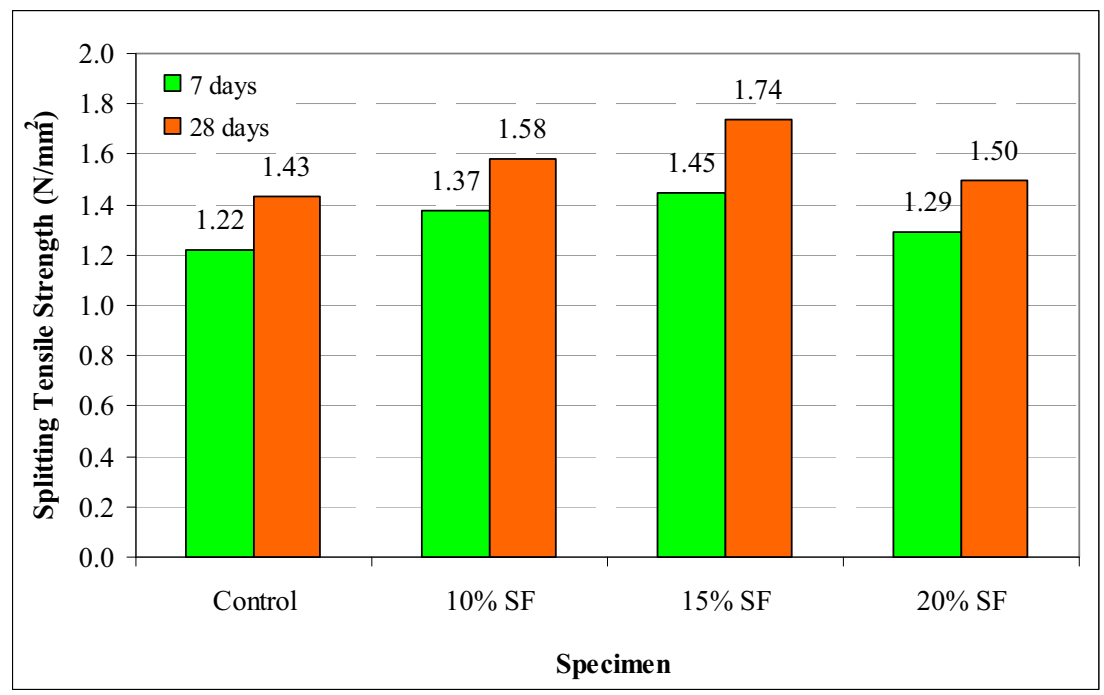

Fig.11: Comparison of splitting tensile strength of different percentages of silica fume at 7 and 28 days

\section{Conclusion}

This study reviewed all the processes from the primary stages of foamed concrete mix design up to the analysis of obtained data. Experimental laboratory works were carried out to obtain data for compressive strength, flexural strength and splitting tensile strength. Results from tests indicate that the compressive strength of foamed concrete is primarily a function of dry density and is only minimally affected by the percentage of cement replaced by silica fume. Essentially, it can be concluded that replacing high proportions of cement with silica fume does not significantly affect the long-term compressive strength of well-cured foamed concrete. Results also show that this strength was observed in all samples, although foamed concrete mixtures with high silica fume content may require a longer period to reach their ultimate strength. Similar research on silica fume has also indicated that the cost of foamed concrete mixtures could be reduced by replacing large volumes of cement without significantly affecting the long-term strength. It is suggested that the ideal percentage of silica fume is $15 \%$ of the binder weight. Improvements in the compressive, flexural and splitting tensile strength of foamed concrete with the use of silica fume is due to the higher rate of reaction between the minerals in the silica fume with foam concrete.

\section{Acknowledgement}

The authors would like to thank the funding bodies of this research: Universiti Sains Malaysia under USM Short Term Grant. No. 304/PPBGN/6312147

\section{References}

1. Short A, Kinniburgh W., 1978. Lightweight concretes. London: Applied Sciences Publishers; p $1-17$

2. Othuman Mydin, M.A., Y.C. Wang, 2011. Structural Performance of Lightweight Steel-Foamed Concrete-Steel Composite Walling System under Compression. Journal of Thin-walled Structures, 49 (1): 66-76 
3. Jones, M. R. \& McCarthy, 2006. A. Heat of hydration in foamed concrete: Effect of mix constituents and plastic density. Cement and Concrete Research, 36 (6): p 1032-1041.

4, Kessler, H. G. 1998. Cellular lightweight concrete, Concrete Engineering International, p 56-60.

5. Othuman Mydin, M.A., Y.C. Wang, 2011. Elevated-Temperature Thermal Properties of Lightweight Foamed Concrete. Journal of Construction \& Building Materials, 25 (2): 705-716

6. Aldridge, D., Ansell, T. 2001. Foamed concrete: production and equipment design, properties, applications and potential. In: Proceedings of one day seminar on foamed concrete: Properties, applications and latest technological developments, Loughborough University, p 1-7

7. Othuman Mydin, M.A., Y.C. Wang, 2012. Mechanical properties of foamed concrete exposed to high temperatures. Journal of Construction and Building Materials, 26 (1): 638-654

8. Othuman Mydin, M.A., 2011. Thin-walled steel enclosed lightweight foamcrete: A novel approach to fabricate sandwich composite. Australian Journal of Basic and Applied Sciences, $\mathbf{5}$ (12): $1727-1733$

9. BCA, 1994. Foamed concrete: Composition and properties. Report Ref. 46.042, Slough: BCA

10. Jones, M. R., McCarthy, 2005. A. Preliminary views on the potential of foamed concrete as a structural material. Mag. Concr. Res. 57 (1): p 21-31.

11. Zulkarnain, F., Ramli, M., 2011. Durability of Performance Foamed Concrete Mix Design with Silica Fume for Housing Development. Journal of Materials Science and Engineering 5: 518527

12. Soleimanzadeh, S., M.A. Othuman Mydin, 2013. Influence of High Temperatures on Flexural Strength of Foamed Concrete Containing Fly Ash and Polypropylene Fiber, International Journal of Engineering, 26 (1): 365-374

13. Othuman Mydin, M.A., 2013. Modeling of Transient Heat Transfer in Foamed Concrete Slab. Journal of Engineering Science and Technology, 8 (3): 331-349

14. Mydin, M.A., Y.C. Wang, 2012. Thermal and mechanical properties of Lightweight Foamed Concrete (LFC) at elevated temperatures. Magazine of Concrete Research, 64 (3): 213-224 